\title{
WORKSHOP ON RESEARCH ISSUES IN ALUMINUM TOXICITY
}

\section{Saturday, July 8, 1995 \\ Vancouver Renaissance Hotel \\ 1133 West Hastings Street, Vancouver, British Columbia}

This workshop will differ from other conferences on aluminum in that the participants will identify and discuss major unresolved/contrcversial issues related to aluminum that warrant future research and suggest research approaches. The key participants addressing each issue will prepare a written summary addressing their issue in advance of the workshop for presentation to the entire delegation on.July 8. Summaries will be published in the Journal of Toxicology and Environmental Health after the conference available as an issue of this journal to workshop registrants.

\section{ISSUES TO BE DISCUSSED:}

1. What are the status and future concerns of clinical and environmental aluminum toxicology? 2. What is the relevance and importance of aluminum chemistry, including biological speciation, to the toxicity of aluminum?

3. What are the unresolved issues of aluminum toxicokinetics, including absorption, distribution and blood-brain barrier permeation that need to be resolved?

4. What do we know and what do we need to know about the effects of aluminum during developmental periods?

5. Can the mechanisms of aluminum-induced neurotoxicity be integrated into a unified scheme? What is that scheme?

6. Can the controversy of the role of aluminum in Alzheimer's disease be resolved? If so, how?

7. Aluminum biological standards: What are the needs?

8. How does aluminum exposure affect bone formation and remodeling, hematopoiesis, and renal function?

9. Do we have adequate chelators or other methods to treat aluminum toxicity?

\section{ORGANIZING COMMITTEE:}

Robert A. Yokel, Ph.D. University of Kentucky John Savory, Ph.D.

University of Virginia

\section{KEY PARTICIPANTS:}

Kenneth Abreo, M.D.

Peter Ackrill, M.D.

Allen C. Alfrey, M D.

Guy Beerthon, Ph.D.

J. Derek Birchall, O.B.E.

Karel Blaha, Ph.D.

Ellen Bllrgess, M.D.

Jorge U. Cannata, Ph.D.

Miroslav Cikrt Ph.D.

J. Philip Day, Ph.D.

Jose L. Domingo, Ph.D.

William D. Ehhmann, Ph.D.
Mari S. Golub, Ph.D.

University of California-Davis
Chris Orvig, Ph.D.

University of British Columbia

Barbara F. Brandt, Ph.D.

University of Kentucky
Louisiana State Univ. Medical Center

University Hospital of South Manchester

University of Colorado

INSERM

University of Keele

Czech Ministry of Environment

University of Calgary

Hospital General Asturias

National Institute of Public Health, Czech Repllblic

University of Manchester

University of Barcelona

University of Kentucky 
Christopher Exley, Ph.D.

Trond Peder Flaten, Ph.D.

William F. Forbes Ph.D.

Ralph M Garruto, Ph.D.

Mari S. Golub, Ph.D.

William G. Goodman, M.D.

Janet L. Greger, Ph .D.

Wesley R. Harris, Ph.D.

Elizabeth H. Jeffery, Ph.D.

Jayant G. Joshi, PhD.

Tamas Kiss, Ph.D.

Theo Kruck, Ph.D.

Mark A. Lovell, Ph.D.

William R. Markesbery, M.D.

R. Bruce Martin, Ph.D.

Sri Melethil, Ph.D.

William R. Mundy, Ph.D.

Chris Orvig, Ph.D.

John Savory, Ph.D.

Timothy J. Shafer ,Ph.D

Michael J. Strong, M D.

Carol R. Swyt, Ph.D.

Ikuro Wakayama, M.D.

David R. Williams, Ph D.

Henry M. Wisniewski, M.D., Ph.D.

Robert A. Yokel, Ph.D.

Khalequz Zamam, Ph.D.

Paolo Zatta, Ph.D.
University of Keele

University of Trodheim

Canadian Center of Health Info.

$\mathrm{NIH}$

University of California, Davis

University of California-Los Angeles

University of Wisconsin-Madison

University of Missouri-St. Louis

University of Illinois-Champaign

University of Tennessee

Lajos Kossuth University

University of Toronto

University of Kentucky

University of Kentucky

University of Virginia

University of Missouri-Kansas City

US EPA

University of British Columbia

University of Virginia

US EPA

University Hospital, University of Western Ontario

$\mathrm{NIH} / \mathrm{BEIP}$

Wakayama Medical College

University of Wales

Institute for Basic Research in Dev Disab

University of Kentucky

University of Nevada

University of Padova

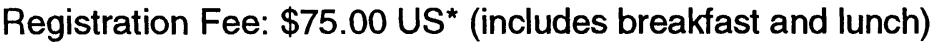

*Discount with joint registration to COMTOX

Vancouver Renaissance Hotel

1133 W. Hastings Street

Phone: (604) 689-92 11

Room rate: $\$ 145.00$ cdn (\$105 US approx)

Rooms will be held until June 6, 1995

Please indicate you are part of the Aluminum Workshop program when making reservations

For more information on this workshop, contact:

\author{
The University of Kentucky \\ Continuing Pharmacy Education \\ 465 E. High Street, Suite 204 \\ Lexington, KY 40507 \\ Phone: (606) 257-7719 Fax: (606) 323-2437
}

